\title{
PREMATURE THELARCHE: IDENTIFICATION OF CLINICAL AND LABORATORY DATA FOR THE DIAGNOSIS OF PRECOCIOUS PUBERTY
}

Thais Della Manna, Nuvarte Setian, Durval Damiani, Hilton Kuperman and Vaê Dichtchekenian

DELLA MANNA T et al. - Premature thelarche: identification of clinical and laboratory data for the diagnosis of precocious puberty. Rev. Hosp. Clín. Fac. Med. S. Paulo 57(2):49-54, 2002.

PURPOSE: Two groups of girls with premature breast development were studied retrospectively. We tried to identify clinical, radiological, and hormonal parameters that could distinguish between a benign, nonprogressive premature thelarche and a true precocious puberty.

METHODS: The clinical outcome of 88 girls with breast enlargement before 6.1 years of age was analyzed. Taking into account the progression of their sexual maturation, we allocated the children into 2 groups: "Isolated Premature Thelarche" $(\mathrm{n}=63)$ and "Precocious Puberty" ( $n=25)$ groups. Chronological and bone ages, height and growth velocity centiles, computerized tomography of hypothalamus-pituitary area, pelvic ultrasonography, gonadotropin response to luteinizing hormone-releasing hormone stimulation as well as basal levels of luteinizing hormone, follicle-stimulating hormone, estradiol, and prolactin were studied in both groups. Statistical analysis were performed using the Student $t$ test to compare the sample means. Fisher's exact test and $\chi^{2}$ test were used to analyze the nonparametric variables.

RESULTS: Isolated premature thelarche most frequently affected girls younger than 2 years who presented exaggerated follicle-stimulating hormone response to luteinizing hormone-releasing hormone stimulation test. The precocious puberty group had higher initial stature, accelerated growth rate and bone age, increased uterine and ovarian volumes, high spontaneous luteinizing hormone levels by immunofluorimetric assay, as well as a high luteinizing hormone response and peak luteinizing hormone/folliclestimulating hormone ratio after luteinizing hormone-releasing hormone stimulation.

CONCLUSION: At initial presentation, girls who undergo true precocious puberty present advanced bone age, increased uterine and ovarian volumes in addition to breast enlargement, as well as an luteinizing hormone -predominant response after a luteinizing hormone-releasing hormone stimulation test.

DESCRIPTORS: Precocious puberty. Premature thelarche. Precocious puberty diagnosis. Pelvic ultrasonography. Luteinizing hormone-releasing hormone stimulation test.

Premature thelarche, the usually benign development of breasts in young girls, has been considered a variation of normal puberty ${ }^{1}$ due to its nonprogressive course. However, at the initial presentation, it is not always easy to distinguish it from a true precocious puberty.

Since 1980, various longitudinal clinical trials and follow-up studies of premature thelarche have been pub- lished. Theories about the cause have become polarized: one confirming the nonprogressive, benign process ${ }^{2-4}$ and the other suggesting that premature thelarche is a consequence of a defect in the hypothalamic-pituitary-ovarian

From the Endocrine Unit of the Children's Institute, Hospital das Clínicas, Faculty of Medicine, University of São Paulo. axis along with an exaggerated peripheral response to sexual hormones ${ }^{5,6}$.

In the early 1970 s, it was observed that follicle-stimulating hormone (FSH) levels in normal girls during the first two years of life were higher than those at late puberty and that FSH levels stimulated by luteinizing hormonereleasing hormone (LHRH) were significantly higher in girls than in boys throughout all pubertal development 
stages. This period of higher FSH production could be responsible for the development of premature thelarche in some girls ${ }^{7,8}$.

The etiology of premature thelarche is still unknown; consequently, no specific marker has been identified to differentiate such a process from the onset of true precocious puberty.

With an intent to identify clinical, radiological, and laboratory features for forecasting the progression to precocious puberty, we performed a retrospective study of 88 girls with premature breast development.

\section{PATIENTS}

\section{Population}

In a 17 -year retrospective study, 88 girls who presented with premature breast enlargement were analyzed according to the following inclusion criteria: breast budding before 6.1 years of age based on Bierich's standards of sexual precocity ${ }^{9}$; breast development corresponding to Tanner ${ }^{10}$ stage $\mathrm{B}_{2}$ or $\mathrm{B}_{3}$ at the first consultation, and a follow-up period of at least 6 months in order to classify their sexual maturation development as "regressive", "stable", or "progressive"3. Girls who presented a "regressive" or "stable" outcome were diagnosed as isolated premature thelarche (IPT), and those with a "progressive" course were diagnosed as precocious puberty (PP).

The isolated premature thelarche group $(n=63)$ presented breast enlargement before 5.5 years of age; the mean age at the first appointment was 2.3 years, and the pubertal stages were $\mathrm{B}_{2} \mathrm{P}_{1}(\mathrm{n}=60)$ or $\mathrm{B}_{3} \mathrm{P}_{1}(\mathrm{n}=3)$; the clinical course was classified as "stable" in 28 girls and "regressive" in 35 .

The precocious puberty group $(\mathrm{n}=$ 25) comprised various etiologies, such as hamartoma $(\mathrm{n}=2)$, chronic encephalopathy $(\mathrm{n}=2)$, hydrocephalus $(\mathrm{n}=1)$ and congenital toxoplasmosis $(n=2)$. Eighteen patients were idiopathic. The girls began breast development from the age of 1 month until 6.1 years; at the first consultation the mean age was 5.4 years, and the pubertal stages were $\mathrm{B}_{2} \mathrm{P}_{1}$ $(\mathrm{n}=8), \mathrm{B}_{2} \mathrm{P}_{2}(\mathrm{n}=6), \mathrm{B}_{2} \mathrm{P}_{3}(\mathrm{n}=3), \mathrm{B}_{3} \mathrm{P}_{1}$ $(\mathrm{n}=1), \mathrm{B}_{3} \mathrm{P}_{2}(\mathrm{n}=4), \mathrm{B}_{3} \mathrm{P}_{3}(\mathrm{n}=3)$; all of them presented "progressive" signs of sexual maturation.

\section{METHOD}

The following variables were studied retrospectively in both groups: chronological age (CA) at onset of thelarche; CA at the first appointment; height centiles calculated from height curves of the National Center for Health Statistics (NCHS) ${ }^{11}$; growth velocity centiles in the first year of follow up using the growth velocity curves of Tanner and Whitehouse ${ }^{12}$; initial bone age (BA) at the first appointment was compared using the standards of Greulich and Pyle ${ }^{13}$ for hands and wrists; bone age after 1 or 2 years of follow up, analyzing the $\triangle \mathrm{BA} / \Delta \mathrm{CA}$ ratio; computerized tomography or magnetic resonance of hypothalamus-pituitary area; pelvic ultrasonography following the standards of Salardi et al. ${ }^{14}$ and Orsini et al. ${ }^{15}$ for uterine and ovarian volumes in children and adolescents, assuming an upper limit for uterine volume of $4 \mathrm{~mL}$ and for ovarian volume of $2 \mathrm{~mL}$ as the normal upper limits for the prepubertal age group; the frequency of the microcystic condition of the ovaries; basal levels of LH and FSH were performed using commercially available radioimmunoassay (RIA) kits (RIA Gnost, Groupe Oris, France) and immunofluorimetric assay (IFMA) kits (Delfia - Pharmacia Diagnostic, Uppsala, Sweden). Gonadotropin response to LHRH (LHRH-Serono, 100 $\mu \mathrm{g}$ in bolus) was assessed by collecting blood samples for determination of
LH and FSH just before the administration of LHRH, and subsequently at 15, 30, 60, and 90 minutes. The basal levels of LH and FSH, the peak levels of LH and FSH, and the peak LH/FSH ratio were analyzed; estradiol and prolactin were performed by RIA using commercially available kits; prolactin measurements were also performed with fluorimetric kits. Informed written consent about the diagnostic tests used was obtained from the parents of all children. Our institutional ethics committee approved this retrospective analysis.

\section{Statistical Analysis}

Statistical analysis was performed by the $\chi^{2}$ test and Fisher's exact test for analysis the nonparametric variables, and the Student $t$ test for differentiating between the means. Statistical significance was considered $P<0.05$.

\section{RESULTS}

Breast enlargement began before 2 years of age in $90 \%$ of the IPT group, but in the PP group, the age distribution was more scattered.

At the time of the first consultation, the IPT group had heights compatible with the normal population mean, with $79 \%$ of the cases below the $90^{\text {th }}$ centile. However, in the PP group, a majority $(60 \%)$ of heights were equal to or greater than the $90^{\text {th }}$ centile $(P<$ 0.001 ).

In the first year of follow up, the growth velocity was below the $90^{\text {th }}$ centile in $78 \%$ of IPT patients, while in the PP group, $76 \%$ were girls ${ }^{3} 90^{\text {th }}$ centile $(P<0.001)$.

Only in the PP group was the initial bone age greater than 2 standard deviations of the mean chronological age, but its progression was similar in both groups for up to 2 years of follow up. 
Computerized tomography or magnetic resonance imaging of the hypothalamus-pituitary area was performed in 16 girls in IPT group and was normal in $88 \%$ of them. In the PP group, 20 girls were analyzed with results as follows: 3 instances of anterior pituitary enlargement (15\%), 2 of tuber cinereum hamartoma (10\%), 2 of periventricular calcification $(10 \%), 2$ of ventricular asymmetry (10\%), 1 of cortical atrophy $(5 \%)$, and 1 of pituitary stalk enlargement $(5 \%)$. Nine $(45 \%)$ were normal.

A uterine volume greater than $4 \mathrm{~mL}$ was found in only 1 out of 28 girls of the IPT group in which pelvic ultrasonography was performed, but in 14 out of 15 girls analyzed in the PP group $(P<0.001)$. An ovarian volume greater than $2 \mathrm{~mL}$ was observed in 1 out of 11 girls in the IPT group, and in all 3 girls analyzed in the PP group $(P<0.001)$. An ovarian microcystic appearance was equally frequent in both groups.

No statistical difference was found between the mean spontaneous LH levels: 7.7 and 4.4 IU/L, and FSH levels: 9.9 and $7.1 \mathrm{IU} / \mathrm{L}$ in the PP group and
IPT group, respectively, when measured with RIA at the time of the first appointment. However, on immunofluorimetric assay (IFMA), the mean spontaneous LH levels were 3.7 and $1.4 \mathrm{IU} / \mathrm{L}$ in the PP and IPT groups, respectively $(P<0.05)$. The mean basal FSH levels by IFMA were 7.9 and $2.4 \mathrm{IU} / \mathrm{L}$ for the PP and IPT groups, respectively $(P>0.05)$ (Table 1$)$.

Upon LHRH stimulation, the mean peak LH response levels measured either with RIA (74.9 IU/L) or by IFMA (34.1 IU/L) were higher in the PP group $(P<0.01)$, but mean peak FSH levels were higher in the IPT group $(P$ $<0.001)$, mainly when measured with RIA (58.6 IU/L) (Table 2).

The peak LH/FSH response ratio was higher in the PP group $(P<0.05)$ either by RIA or by IFMA (Table 2).

The mean spontaneous estradiol levels measured with RIA were 25.5 and $11.9 \mathrm{pg} / \mathrm{mL}$ in the PP and IPT groups, respectively, and were not statistically different $(\mathrm{P}=0.83)$. Prolactin levels were not statistically different between groups, as measured by either method (RIA or IFMA).

\section{DISCUSSION}

In the IPT group, the clinical manifestation of breast enlargement usually started before 2 years of age $(90.5 \%$ of the cases) as has already been observed by others ${ }^{4,5,7,8}$. In the PP group, this age distribution was not seen.

In our patients, the bilateral breast budding was the rule in both groups without noticeable fluctuations in size in the IPT group, contrasting with reports by Stanhope et al. ${ }^{16}$.

The height centile of the IPT group at presentation was compatible with the norm, but in the PP group the children were predominantly taller for their chronological age. Likewise, the growth velocity centile was higher in the PP group ( $90^{\text {th }}$ centile) during the first year of clinical follow up. Many authors consider that the accelerated growth velocity could be considered as a sign of precocious puberty ${ }^{17-19}$.

The PP group had advanced bone age at the first appointment (> 2 SD for the mean age of 5.4 years), but in the IPT group, the bone age was compatible with the girls' chronological age

Table 1 - Comparison between spontaneous hormonal levels in precocious puberty and IPT groups.

\begin{tabular}{|c|c|c|c|}
\hline $\begin{array}{l}\text { Hormone: } \\
\text { Immunoassay method (normality) }\end{array}$ & $\begin{array}{c}\text { Precocious Puberty } \\
\text { Spontaneous levels } \\
\text { Mean (SD) }\end{array}$ & $\begin{array}{c}\text { IPT } \\
\text { Spontaneous levels } \\
\text { Mean (SD) }\end{array}$ & Student's $t$ test \\
\hline \multicolumn{4}{|l|}{ Spontaneous luteinizing hormone levels: } \\
\hline Radioimmunoassay ( 1.8 - 13 IU/L) & $\begin{array}{c}7.7(6.9) \mathrm{IU} / \mathrm{L} \\
(n=15)\end{array}$ & $\begin{array}{c}4.4(3.0) \mathrm{IU} / \mathrm{L} \\
(n=28)\end{array}$ & $P=0.1020$ \\
\hline Immunofluorimetric assay (0.6 - $1.3 \mathrm{IU} / \mathrm{L})$ & $\begin{array}{c}3.7(2.3) \mathrm{IU} / \mathrm{L} \\
(n=9)\end{array}$ & $\begin{array}{c}1.4(1.2) \mathrm{IU} / \mathrm{L} \\
(n=15)\end{array}$ & $P=0.0167$ \\
\hline \multicolumn{4}{|c|}{ Spontaneous follicle-stimulating hormone levels: } \\
\hline Radioimmunoassay ( $3.0-12$ IU/L) & $\begin{array}{c}9.9(4.9) \mathrm{IU} / \mathrm{L} \\
(n=15)\end{array}$ & $\begin{array}{c}7.1(4.3) \mathrm{IU} / \mathrm{L} \\
(n=28)\end{array}$ & $P=0.0778$ \\
\hline Immunofluorimetric assay (1.0 - 3.1 IU/L) & $\begin{array}{c}7.9(10.2) \mathrm{IU} / \mathrm{L} \\
(n=9)\end{array}$ & $\begin{array}{c}2.4(0.9) \mathrm{IU} / \mathrm{L} \\
(n=15)\end{array}$ & $P=0.1457$ \\
\hline \multicolumn{4}{|l|}{ Spontaneous Estradiol: } \\
\hline Radioimmunoassay $(<20$ pg/mL) & $\begin{array}{c}25.5(31.4) \mathrm{pg} / \mathrm{mL} \\
(n=13)\end{array}$ & $\begin{array}{c}11.9(18.2) \mathrm{pg} / \mathrm{mL} \\
(n=44)\end{array}$ & $P=0.0832$ \\
\hline \multicolumn{4}{|l|}{ Spontaneous Prolactin: } \\
\hline Radioimmunoassay ( $5.0-25 \mathrm{ng} / \mathrm{mL}$ ) & $\begin{array}{c}11.6(10.0) \mathrm{ng} / \mathrm{mL} \\
(n=12)\end{array}$ & $\begin{array}{l}9.1(8.5) \mathrm{ng} / \mathrm{mL} \\
(n=28)\end{array}$ & $P=0.4691$ \\
\hline Immunofluorimetric assay $(<14$ ng/mL $)$ & $\begin{array}{c}11.8(8.1) \mathrm{ng} / \mathrm{mL} \\
(\mathrm{n}=5)\end{array}$ & $\begin{array}{c}8.9(4.8) \mathrm{ng} / \mathrm{mL} \\
(n=9)\end{array}$ & $P=0.4968$ \\
\hline
\end{tabular}


Table 2 - Comparison between peak luteinizing hormone and follicle-stimulating hormone levels and peak Luteinizing hormone/follicle-stimulating hormone ratio upon luteinizing hormone-releasing hormone stimulation test in precocious puberty and IPT groups.

\begin{tabular}{|c|c|c|c|}
\hline $\begin{array}{l}\text { Luteinizing hormone- } \\
\text { releasing hormone stimulation test: } \\
\text { immunoassay method (normality) }\end{array}$ & $\begin{array}{l}\text { Precocious Puberty } \\
\text { Mean hormone levels } \\
\text { (SD) }\end{array}$ & $\begin{array}{l}\text { IPT } \\
\text { Mean hormone levels } \\
\text { (SD) }\end{array}$ & Student $t$ test \\
\hline \multicolumn{4}{|l|}{ Peak luteinizing hormone levels: } \\
\hline Radioimmunoassay (> 15 IU/L ) & $\begin{array}{l}74.9(68.1) \mathrm{IU} / \mathrm{L} \\
\quad(n=15)\end{array}$ & $\begin{array}{l}19.4(11.3) \mathrm{IU} / \mathrm{L} \\
\quad(n=29)\end{array}$ & $P=0.0071$ \\
\hline Immunofluorimetric assay $(0.96-6.9 \mathrm{IU} / \mathrm{L})$ & $\begin{array}{c}34.1(20.7) \mathrm{IU} / \mathrm{L} \\
(n=9)\end{array}$ & $\begin{array}{l}4.5(3.0) \mathrm{IU} / \mathrm{L} \\
\quad(n=15)\end{array}$ & $P=0.0042$ \\
\hline \multicolumn{4}{|l|}{ Peak follicle-stimulating hormone levels: } \\
\hline Radioimmunoassay (> 20 IU/L ) & $\begin{array}{l}31.3(20.5) \mathrm{IU} / \mathrm{L} \\
\quad(n=15)\end{array}$ & $\begin{array}{l}58.6(28.6) \mathrm{IU} / \mathrm{L} \\
\quad(n=29)\end{array}$ & $P=0.0008$ \\
\hline Immunofluorimetric assay (6.7 - $24.5 \mathrm{IU} / \mathrm{L})$ & $\begin{array}{c}16.3(13.1) \mathrm{IU} / \mathrm{L} \\
(\mathrm{n}=9)\end{array}$ & $\begin{array}{l}24.4(8.7) \mathrm{IU} / \mathrm{L} \\
\quad(n=15)\end{array}$ & $P=0.1239$ \\
\hline \multicolumn{4}{|l|}{$\begin{array}{l}\text { Peak luteinizing hormone / follicle-stimulating } \\
\text { hormone ratio: (prepubertal levels) }\end{array}$} \\
\hline Radioimmunoassay $(<0.66)$ & $\begin{array}{l}2.44(2.96) \\
(n=15)\end{array}$ & $\begin{array}{l}0.33(0.17) \\
(n=29)\end{array}$ & $P=0.0153$ \\
\hline Immunofluorimetric assay $(<0.3)$ & $\begin{array}{l}2.86(2.05) \\
\quad(n=9)\end{array}$ & $\begin{array}{l}0.18(0.09) \\
(n=15)\end{array}$ & $P=0.0043$ \\
\hline
\end{tabular}

(mean $=2.3$ years). In our population, analysis of the advance in bone age during a 1-2 year observation period did not differentiate between the two groups.

Several authors ${ }^{14,20}$ using ultrasonography have concluded that in premature thelarche, ovarian and uterine volumes are normal and the ovarian microcysts are quite frequent. In the PP group of the present study, however, these volumes are higher, and the appearance of larger follicular cysts is very frequent. In the present study, the increase in the uterine and ovarian volumes was only associated with the PP group; ovarian microcysts were observed in both groups and thus were not a useful means of distinguishing between them.

Random spontaneous LH levels measured by RIA have never enabled the diagnosis and monitoring of the onset of puberty. This limitation has been explained by the intermittent and nocturnal pattern of LH secretion reflecting the episodic activity of the LHRH neurons. In the late 1980s, with the introduction of immunometric assays, a greater correlation index between such immunoassays and the bioactivity of LH was observed. Many authors ${ }^{21-23}$ found a significant difference between the random spontaneous LH levels of prepubertal and pubertal populations, thus indicating their value as a biochemical marker of puberty. No such difference was obtained for FSH levels.

In the present study, at the first medical appointment, the random spontaneous LH and FSH levels measured with RIA were compatible with the normal values for the method and did not differentiate between the IPT and PP groups. However, when measured with IFMA, it was possible to differentiate the PP group, which had higher mean spontaneous LH levels. In our population, no difference occurred in the mean random spontaneous FSH levels between the IPT and PP groups whether measured by RIA or IFMA.

Pescovitz et al. ${ }^{18}$ used the LHRH stimulation test to differentiate IPT from the initial manifestation of central precocious puberty and observed that the IPT group had FSH-predominant responses to LHRH, but those with complete sexual development had LHpredominant responses after stimulation; the intermediate groups had a great variation of plasma $\mathrm{LH}$ and $\mathrm{FSH}$ responses to LHRH. Oerter et al. ${ }^{24}$ revised and enlarged this study and concluded that the response to LHRH stimulation was the most useful variable in distinguishing between pubertal and prepubertal girls. Furthermore, a peak LH to peak FSH ratio above 0.66 , measured with RIA, had $96 \%$ sensitivity and $100 \%$ specificity for diagnosing pubertal gonadotropin secretion in girls. The response to LHRH stimulation is still the gold standard for diagnosing puberty; however, the ultrasensitive immunometric methods have allowed a reduction in the number of blood samples to a collection between 20 to 40 minutes after a LHRH bolus $(100 \mu \mathrm{g})$, and the peak LH/FSH ratio above 0.33 is indicative of puberty ${ }^{25,26}$.

In our population after LHRH stimulation, peak LH levels were significantly higher in the PP group, whether measured by RIA or by IFMA. On the other hand, the IPT group had peak FSH levels significantly higher as 
determined by RIA, but not with IFMA. The peak LH/FSH ratio was significantly higher in the PP group, both with RIA and IFMA. Lee ${ }^{25}$ has suggested that peak LH levels higher than $15 \mathrm{IU} /$ L with RIA and higher than $6 \mathrm{IU} / \mathrm{L}$ with IFMA and a peak LH/FSH ratio higher than 0.66 (RIA) and higher than 0.3 (IFMA) may be used as diagnostic markers of pubertal activation in girls.

The spontaneous prolactin levels measured either by RIA or fluorimetric assay were not useful in differentiating between the IPT and PP groups. The PP group had a mean estradiol level slightly higher than normal; however, this difference was not statistically significant in relation to that of the IPT group. This finding emphasizes the low sensitivity of most estradiol immunoassays used recently, and perhaps suggests that the utilization of a biological assay such as hormonal vaginal or urinary cytology, indicating the level of cell estrogenization, would be of greater diagnostic value ${ }^{5,27}$.

Our data indicate that a girl could present true precocious puberty when, in addition to premature breast development, advanced bone age and increased uterine and ovarian volumes as determined by pelvic ultrasonography, are observed. We conclude that an LH-predominant response after a LHRH stimulation test appears to be an effective parameter in differentiating IPT from PP.
DELLA MANNA T e col. - Telarca precoce: identificação de dados clínicos e laboratoriais preditivos para o diagnóstico de puberdade precoce. Rev. Hosp. Clín. Fac. Med. S. Paulo 57(2):49-54, 2002.

OBJETIVO: A fim de distinguir o quadro de telarca precoce, benigno e auto-limitado, do início de um processo de puberdade precoce verdadeira estudamos, retrospectivamente, dois grupos de meninas com desenvolvimento mamário prematuro, buscando identificar parâmetros clínicos, radiológicos e laboratoriais relacionados a cada quadro.

MÉTODOS: A evolução clínica de 88 meninas que apresentaram broto mamário antes dos 6,1 anos de idade foi analisada e classificada, segundo a progressão dos caracteres sexuais secundários, em um grupo portador de "Telarca Precoce Isolada" $(n=63)$ e um grupo portador de "Puberdade Precoce" $(n=25)$. Foram analisados ida- de cronológica, estatura inicial e velocidade de crescimento em percentis, idade óssea, tomografia computadorizada de hipotálamo-hipófise, ultrasonografia pélvica, resposta gonadotrófica ao teste de estímulo pelo hormônio liberador do hormônio luteinizante, assim como níveis basais dos hormônios luteinizante, folículoestimulante, estradiol e prolactina nos dois grupos. A análise estatística foi realizada pelo teste $\mathrm{t}$ de Student para comparação entre médias e pelos testes do $\chi^{2}$ e exato de Fisher para variáveis não paramétricas.

RESULTADOS: A telarca precoce isolada afetou meninas menores de 2 anos, com resposta exagerada de hormônios luteinizante, folículo-estimulante no teste do hormônio liberador do hormônio luteinizante. O grupo puberdade precoce apresentou estatura inicial mais elevada, aceleração da velocidade de crescimento e da idade óssea, aumento dos volumes uterino e ovariano, níveis de hormônios luteinizante basais elevados pelo ensaio imunofluorimétrico, com resposta exagerada de hormônios luteinizante e aumento da relação de pico/hormônios luteinizante, folículo-estimulante no teste do hormônio liberador do hormônio luteinizante.

CONCLUSÃO: Frente a um quadro de desenvolvimento mamário prematuro, a presença de idade óssea avançada e aumento dos volumes uterino e ovariano à ultra-sonografia pélvica sugerem puberdade precoce verdadeira, que deverá ser confirmada por resposta predominante do hormônio luteinizante no teste de estímulo com hormônio liberador do hormônio luteinizante.

DESCRITORES: Puberdade precoce. Telarca precoce. Diagnóstico de puberdade precoce. Ultra-sonografia pélvica. Teste de estímulo do hormônio liberador do hormônio luteinizante. 


\section{REFERENCES}

1. ROSENFIELD RL - Normal and almost normal precocious variations in pubertal development premature pubarche and premature thelarche revisited. Horm Res 1994; 41(suppl 2):7-13.

2. MiLlS JL, STOLLEY PD, DAVIES J et al. - Premature thelarche. Natural history and etiologic investigation. Am J Dis Child 1981; 135:743-5.

3. CUELLO XA, VIVANCO XW \& ABODOVSKY NG - Telarquia prematura. Rev Chil Pediatr 1985; 56:27-33.

4. VAN WINTER JT, NOLLER KL, ZIMMERMAN D et al. - Natural history of premature thelarche in Olmsted County, Minnesota, 1940 to 1984. J Pediatr 1990; 116:278-80.

5. ILICKI A, LEWIN RP, KAULI R et al. - Premature thelarche - Natural history and sex hormone secretion in 68 girls. Acta Paediatr Scand 1984; 73:756-62.

6. PASQUINO AM, TEBALDI L, CIOSCHI L et al. - Premature thelarche: a follow up study of 40 girls. Natural history and endocrine findings. Arch Dis Child 1985; 60:1180-92.

7. FAIMAN C \& WINTER JSD - Sex differences in gonadotrophin concentrations in infancy. Nature 1971; 232:130.

8. JOB JC, GARNIER PE, CHAUSSAIN JL et al. - Effect of synthetic luteinizing hormone-releasing hormone (LH-RH) on the release of gonadotropins in hypophyso-gonadal disorders of children and adolescents. II. Precocious puberty and premature thelarche. Biomedicine 1973; 19:77-81.

9. BIERICH JR - Sexual precocity. Clin Endocrinol Metab 1975; 4:10742.

10. MARSHALL WA \& TANNER JM - Variation in pattern of pubertal changes in girls. Arch Dis Child 1969; 44:291-303.

11. NATIONAL Center for Health Statistics - NCHS Growth Curves for Children 0-18 years.- United States, Vital and Health Statistics. Washington, DC, Health Resources Administration, US Government Printing Office, 1977: (Series 11, No 165).

12. TANNER JM \& WHITEHOUSE RH - Clinical longitudinal standards for height, weight, height velocity, weight velocity, and stages of puberty. Arch Dis Child 1976; 51:170.

13. GREULICH WW \& PYLE SI - Radiographic atlas of skeletal development of the hand and wrist. $2^{\text {nd }}$ ed. Stanford, California, Stanford University Press, 1955.

14. SALARDI S, ORSINI LF, CACCIARI E et al. - Pelvic ultrasonography in premenarcheal girls: relation to puberty and sex hormone concentrations. Arch Dis Child 1985; 60:120-5.
15. ORSINI LF, SALARDI S, PILU G et al. - Pelvic organs in premenarcheal girls: real-time ultrasonography. Radiology 1984 153:113-6.

16. STANHOPE R, ADAMS J \& BROOK CGD - Fluctuation of breast size in isolated premature thelarche [letter]. Acta Paediatr Scand 1985; 74:454-5.

17. STANHOPE R \& BROOK CCD - Thelarche variant: a new syndrome of precocious sexual maturation? Acta Endocrinol (Copenh) 1990; 123:481-6.

18. PESCOVITZ OH, HENCH KD, BARNES KM et al. - Premature thelarche and central precocious puberty: the relationship between clinical presentation and the gonadotropin response to luteinizing hormone-releasing hormone. J Clin Endocrinol Metab 1988; 67:474-9.

19. TENORE A, FRANZESE A, QUATTRIN T et al. - Prognostic signs in the evolution of premature thelarche by discriminant analysis. $\mathbf{J}$ Endocrinol Invest 1991; 14:375-81.

20. FREEDMAN SM, KREITZER PM, ELKOWITZ SS et al. - Ovarian microcysts in girls with isolated premature thelarche. J Pediatr 1993; 122:246-9.

21. APTER D, CACCIATORE B, ALFTHAN H et al. - Serum luteinizing hormone concentration increases 100 -fold in females from 7 years of age to adulthood, as measured by time-resolved immunofluorimetric assay. J Clin Endocrinol Metab 1989; 68:53-7.

22. GARIBALDI LR, PICCO P, MAGIER S et al. - Serum luteinizing hormone concentration, as measured by a sensitive immunoradiometric assay, in children with normal, precocious or delayed pubertal development. J Clin Endocrinol Metab 1991; 72:888-98.

23. NEELY EK, WILSON DM, LEE PA et al. - Spontaneous serum gonadotropin concentrations in the evaluation of precocious puberty. J Pediatr 1995; 127:47-52.

24. OERTER KE, URIARTE MM, ROSE SR et al. - Gonadotropin secretory dynamics during puberty in normal girls and boys. J Clin Endocrinol Metab 1990; 71:1251-8.

25. LEE PA - Laboratory monitoring of children with precocious puberty Arch Pediatr Adolesc Med 1994; 148:369-376.

26. ECKERT KL, WILSON D, BACHRACH LK et al. - A single-sample, subcutaneous gonadotropin-releasing hormone test for central precocious puberty. Pediatrics, 1996; 97:517-9.

27. LENCIONE LJ - Urocitograma. $3^{\text {rd }}$ ed. Buenos Aires, Panamericana, 1972 